\title{
The Effects of Different Doses of Equine Chorionic Gonadotropin on Induction of Estrus and Reproductive Patterns in Assaf Ewes out of Breeding Season
}

\author{
Hatem Atalla* \\ Department of Veterinary Medicine, Faculty of Agriculture and Veterinary Medicine, An- \\ Najah National University, Nablus, Palestine \\ *Corresponding author
}

A B S T R A C T

\begin{tabular}{|l|}
\hline Ke y w or d s \\
Assaf, Ewe, Estrus, \\
Progesterone, eCG \\
\hline Article Info \\
\hline $\begin{array}{l}\text { Accepted: } \\
18 \text { May } 2018 \\
\text { Available Online: } \\
\text { 10 June } 2018\end{array}$ \\
\hline
\end{tabular}

This experiment was conducted to investigate the effect of equine chorionic gonadotropin (eCG) levels on estrus response, onset and duration of estrus, lambing rate and litter size in Assaf ewes. A total of 80Assaf ewes were used in the experiment which was conducted during April, 2016, a month that is considered as non-breeding period in Palestine. Ewes were treated with intravaginal sponges containing $60 \mathrm{mg}$ medroxyprogesterone acetate (MAP). Following withdrawal of sponges at day 14, 30ewes from each treatment groups were injected intramuscularly with 300 or $600 \mathrm{IU}$ (eCG), while the control group $(\mathrm{n}=20)$ receive nothing. The results showed that level of eCG had no significant effects on the tested parameters. This finding indicated that low level of eCG can be successfully applied for estrus synchronization in Assaf breed out of the breeding season. Results showed that using sponge followed by a $300 \mathrm{IU}$ dose of eCG could induce estrus successfully with low cost comparing to application of high doses of eCG.

\section{Introduction}

Palestine has been famous for raising sheep for thousands of years. It is one of the oldest professions known to the Palestinian farmer who has a valuable experience in raising it. Almost no house in the countryside is free of sheep or goats which used to meet the needs of the family. Sheep population was estimated to be about 744 thousand heads (PCBS (2008) Palestine in Figures 2007 (PNA). In Palestine, the local "Awassi" breed remained as the main breed of sheep, until the most common hybrids were introduced, the Assaf breed, which is the product of crossbreeding the
Awassi and East Friesian breeds (Goot 1986). Meat and milk production varies from country to country due to cultural and religious reasons, Lamb meat is one of the most pleasant and most expensive meet type in Palestine. At the same time, sheep's milk is considered the main source of local cheese production. According to the evaluations made in recent years, it has been found that the production of sheep in Palestine has not undergone a notable change and have been reversed. To solve this problem, it is necessary to make current production models and reproductive technologies used in the world applicable in our country. It is possible to 
improve yield characteristics and animal incomes if breeding and artificial insemination studies are carried out together with developed organization programs, as seen in examples of developed countries in animal production. Estrus induction and synchronization, which are among the biotechnological developments in recent years, will be able to solve some problems of sheep production as well as form the basis for breeding and artificial insemination programs. Out-of-season lamping ensures that lambs can reach adequate weights when feed sources are adequate before the beginning of dry summer. Adjusting the births according to the desired time provides more effective utilization of grassland and pasture. Estrous control and synchronization can provide convenience and economic benefits for the care and feeding of animals and for the use of buildings and other resources. The major problems that faces the sheep farmers in Palestine is reproduction management (estrus synchronization), this is necessitates looking for reproductive techniques, which could help the farmer, and decrease the cost of production. Palestine is located along the line 14-34 and 40 - 35 east and between latitudes 30-29 and 15-33 in the north. The peak of ewes breeding activity occurs in the period from September to November and lambing activity in months of February to April. Because sheep are seasonally polyestrous, an attempt to mate at a frequency greater than once a year will require one breeding season during anestrous. Without intervening treatments during anestrous, little ovarian and estrous activity occurs, and pregnancy and conception rates are low. Different methods of estrus synchronization were investigated worldwide, such as introduction of rams, (Rosa and Bryant 2002; Chanvallon, Blache et al., 2010) , progesterone (Boscos, Samartzi et al., 2002; Husein and Kridli 2002; Karaca, Ataman et al., 2009), prostaglandins, (Ataman, Akoz et al., 2006; Ataman and Aköz 2006;
SÖZBİLIR, Maraşli et al., 2006) and melatonin, (Stellflug, Fitzgerald et al., 1988; O'callaghan, Karsch et al., 1991; Carlson 2000) . Several researchers aimed to investigate the efficiency of synchronization using different progesterone treatments outside the natural breeding season. Greyling and Van der nest. (Greyling and Van der Nest 2000) investigated that there was no attribution in synchronization efficiency related to different doses of progesterone levels, but the interval of estrus after removal of sponge until estrus induction were shorter at low levels of MAP than with high levels. In addition, others reported that the duration of estrus are shorter in MAP/PGF2 $\alpha$ treatment compared to MAP alone treatment (Ahmed, Makawi et al., 1998; Dogan and Nur 2006) . Ovulation rate in ewes is lower when induced during anestrus than during the breeding season. Ovulation rates were increased by injection of gonadotropins such as equine chorionic gonadotropin (eCG), follicle stimulating hormone (FSH), human chorionic gonadotropin (hCG) and mixed gonadotropin preparations, such as PG 600. (Knights, Baptiste et al., 2003) . Some researchers studied the effect of different PMSG doses on pregnancy and lambing rate in different sheep breeds. Fallah and Farzaneh, (Rad and Farzaneh 2007) used CIDR-G and different levels of PMSG (i.e. 300, 400, 500 and 600 IU) in Balouchi Ewes, and reported that twining rates were higher when using 600IU of PMSG compared to 400 or $300 \mathrm{I}$. U. Other researchers used different levels of PMSG (500, 600, 750IU) in breeding season, and reported that pregnant rate and litter size were increased when high doses of PMSG were used (Timurkan and Yildiz 2005). Akoz et al., (Akoz, Bulbul et al., 2006) used 30mg, 40mg FGA with different doses PMSG (300, $500,700 \mathrm{IU})$, they reported that injection of 700 I. U. of PMSG was more effective in pregnant rate and lambing rate regardless of the dose of FGA. The average interval from 
sponge removal to onset of estrus was studied by Fonseca et al., (Fonseca, Bruschi et al., 2005) who reported that the interval was 49.7 \pm 15 . 7hrafter injection of $200 \mathrm{IU}$.

As there are individual differences in regard the response to hormone treatment, different responses could be present between different breeds. The objectives of this study were to investigate the effect of using intravaginal sponges followed by different eCG doses on estrus response, onset and duration of estrus, lambing rate, and litter size in Assaf ewes in north West Bank of Palestine.

\section{Materials and Methods}

Eighty 3-5 years old Assaf ewes with $65-70 \mathrm{~kg}$ average body weight and 6 healthy Assaf rams aged 3-4 years weighing 90-100kg. were used in this study. This study was carried out in special farm near Nablus city, Palestine. All ewes had previously lambed and weaned their last lamb. Estrous induction and synchronization was conducted out of the natural breeding season.

The animals were kept indoor at night and had access to natural grazing area for most of the day. Indoor ewes were offered diets of concentrated feed with wheat straw. Water and mineral licks were available ad libitum. Ewes were distributed randomly in a factorial design. The ewes portioned into 3 groups with 30 ewes in each treatment group and 20 ewes for the control group, as showed in Table 1.

\section{Group I: (control group)}

The control group of the study consisted of 20 breeding stocks. No hormones or medicines have been applied to the sheep in this group. However, all other applications for evaluation purposes (introduction of teaser rams, resentment, etc.) were applied simultaneously to the control group.

\section{Group II: (300 I. U eCG)}

Received hormonal treatments comprised of intravaginal sponges impregnated with $60 \mathrm{mg}$ medroxyprogesterone acetate (MAP) (SyncroBreed, The Advanced Veterinary Manufacturing Co. Ltd/ Palestine) sponges were inserted for 14 days followed by an intramuscular injection of $300 \mathrm{I}$. U of eCG (AVCP Manufacturing Co. - Ramallah Palestine) at time of sponge removal.

\section{Group III: (600 I. U. eCG)}

Received the same progesterone treatment as in groupII, but instead of $300 \mathrm{I}$. U of eCG, ewes were injected with $600 \mathrm{I}$. U at sponge removal.

At the day of sponge removal and eCG injection, 4 teaser rams were allowed to run with the treated ewes. Estrus was monitored every 6 hours for 3 days. Ewes that detected by teaser rams have been introduced to the rams to be bred. Following sponge removal, reproductive parameters were recorded and evaluated for each animal of the three groups. These parameters were: Incidence of estrus, onset of estrus, duration of estrus, pregnancy rates, lambing rates and litter size.

\section{Blood Progesterone Hormone Analysis}

To follow the changes in progesterone hormone levels, blood samples were taken from jugular Vein before sponge insertion, at day 14, 18and 34 following sponge insertion from ewes of all treated groups. Blood serum were harvested and stored in $1 \mathrm{ml}$ Eppendorf tube at $-20^{\circ} \mathrm{C}$ until the measurement time. Progesterone levels were analyzed according to the procedure provided with Ovine Progesterone ELISA Test purchased from Endocrine Technologies, INC. USA. (Ovine Progesterone ELISA Test - Endocrine Technologies, INC. USA). Briefly, $50 \mathrm{ml}$ of 
standard samples and controls were prepared, $100 \mathrm{ml}$ of progesterone enzyme solution was added to (standard, samples and control) followed by mixing for $30 \mathrm{sec}$. solutions were incubated at $37 \mathrm{C}$ for 1hour. Wells were washed 5 times with washing solution (250$300 \mathrm{ml} /$ well) and $100 \mathrm{ml}$ of substrate solution was added to each well and then incubated at room temperature for 20 minutes without shaking. Afterward, $50 \mathrm{ml}$ stop solution was added to each well. ELISA Plate Reader (Digital and analog system "DAS", Italy) was used to read the absorbance at 450nm and then the concentration for stander, samples, control and blank were calculated.

\section{Statistical Analysis}

All data were analyzed using the SPSS (SPSS Inc. (2008): (SPSS 16 for windows. Statistical package for the social. Sciences) using oneway ANOVA (SPSS INC: SPSS 16 for windows. Statistical package for the social. Sciences. Chicago) .

\section{Results and Discussion}

In this study, changes in reproductive patterns and progesterone hormones concentration were evaluated after administration of different eCG doses. In order to determine whether the animals used in the study were in the anestrus period, rams were introduced between the animals before the hormonal applications were started.

Out of the80Assaf ewes used in the trial, 50 ewes exhibited signs of estrus during the 120 hrs. observation period. However estrus responses were $80 \%$ for both second and third groups and $10 \%$ for the first (control) group, respectively. (Table 2). The time from sponge withdrawal to estrous and the duration of the induced estrus period following two different eCG doses are shown in Table 2. The time from sponge withdrawal to the onset of estrus was not significantly different between the two eCG doses. The time to estrus was slightly longer $(60.7 \mathrm{hrs}$.) in the groups treated $300 \mathrm{I}$. U eCG compared to the second group (51.3 hrs.), but the longest period was in the control group (70.4 hrs.). Duration of estrus are shown in Table 2. This parameter was significantly shorter in the group treated with 600 I. U compared to the first group treated with $300 \mathrm{I}$. U eCG $(P<0$. 05). The estimated litter size for the various levels of eCG treatment are shown Table 2.

Although, 2 ewes from the control group displayed estrus signs, they didn't conceive. Although there was no statistically significant difference in terms of litter size according to the comparison between the $300 \mathrm{IU}$ and 600 IU groups that constituted the main experimental groups of the study, the litter size from the $600 \mathrm{IU}$ group was higher than the other group (1, 37 and 1, 30 respectively) $(P>0.05)$.

Out of 44 pregnant ewes, 58 lambs were obtained. The number of lambs obtained from ewes (i.e. 20 ewes) treated with 300 IU PMSG was 26, however, 32 lambs were obtained from ewes (i.e. 24 ewes) receiving $600 \mathrm{IU}$ PMSG.

The mean progesterone level in the Control group remained below $1 \mathrm{ng} / \mathrm{ml}$. In 2 ewes showing sexual activity, pregnancy and lambing have not been occurred. In the $300 \mathrm{I}$. $\mathrm{U}$ group, the maximum elevation of the progesterone hormone was 7. $64 \mathrm{ng} / \mathrm{ml}$, while it increased to $13.26 \mathrm{ng} / \mathrm{ml}$ in $600 \mathrm{I}$. U group. The mean values as showed in Table 3 were significantly higher in the $600 \mathrm{I}$. U group compared to the other groups $(P<0.05)$.

The percentage of ewes exhibiting estrus in this trial was comparable to values reported by Simonetti and Dogan, (Simonetti, Blanco et al., 2000; Dogan and Nur 2006). 
Table.1 Treatment groups and experimental design

\begin{tabular}{|l|l|l|l|}
\hline Treatment Groups & N & Progesterone Treatment & PMSG Treatment \\
\hline Group I (Control) & 20 & No Sponge & No Hormone \\
\hline Group II & 30 & 60mg MAP for 14 days & 300 I. U eCG \\
\hline Group III & 30 & $60 \mathrm{mg}$ MAP for 14 days & 600 I. U eCG \\
\hline
\end{tabular}

Table.2 Estrus parameters, pregnancy rates and litter size following estrous synchronization with different eCG Doses.

\begin{tabular}{|l|l|l|l|}
\hline & $\begin{array}{l}\text { Group I } \\
\text { (Control) }\end{array}$ & $\begin{array}{l}\text { Group II } \\
300 \text { I. U eCG }\end{array}$ & $\begin{array}{l}\text { Group III } \\
600 \text { I. U eCG }\end{array}$ \\
\hline No. & 20 & 30 & 30 \\
\hline Estrus Response (\%) & $2(10)$ & $24(80)$ & $24(80)$ \\
\hline Onset of estrus (h) & $70.4 \pm 30.4^{\mathrm{a}}$ & $60.7 \pm 20.3^{\mathrm{a}}$ & $51.3 \pm 25.2^{\mathrm{a}}$ \\
\hline Duration of estrus (h) & $12 \pm 2^{\mathrm{b}}$ & $26.4 \pm 4^{\mathrm{a}}$ & $12.1 \pm 7.3^{\mathrm{b}}$ \\
\hline Pregnant ewes (\%) & $0(0)$ & $20(83.30)$ & $24(100)$ \\
\hline Lambed ewes & 0 & 20 & 24 \\
\hline $\begin{array}{l}\text { Number of lambs } \\
\text { (litter size) }\end{array}$ & 0 & $26(1.30)$ & $32(1.37)$ \\
\hline
\end{tabular}

Means bearing different superscripts through the same raw differ significantly $(\mathrm{P}<0.05)$

Table.3 Progesterone Levels $(\mathrm{ng} / \mathrm{ml})$ within days from sponge insertion, Day $0=$ sponge insertion/ Day $14=$ Sponge removal

\begin{tabular}{|l|l|l|l|l|}
\hline & 0 & 14 & $\begin{array}{l}18\left(^{\text {th }} \text { day after }\right. \\
\text { sponge withdrawal) }\end{array}$ & $\begin{array}{l}34 \text { (20 }^{\text {th }} \text { day after } \\
\text { sponge removal) }\end{array}$ \\
\hline Group 1 (control) & 0.33 & $0.30^{\mathrm{c}}$ & $0.27^{\mathrm{b}}$ & $0.65^{\mathrm{c}}$ \\
\hline Group 2 & 0.29 & $1.45^{\mathrm{b}}$ & $1.2^{\mathrm{a}}$ & $6.40^{\mathrm{b}}$ \\
\hline Group 3 & 0.34 & $2.50^{\mathrm{a}}$ & $0.96^{\mathrm{a}}$ & $8.95^{\mathrm{a}}$ \\
\hline
\end{tabular}

Means bearing different superscripts down a column differ significantly $(\mathrm{P}<0.05)$

However, Dogan, (Dogan and Nur 2006) reported $88,9 \%$ estrus response by using 60 $\mathrm{mg}$ of MAP and $500 \mathrm{IU}$ of PMSG during nonbreeding season. Using MAP at level of 60 $\mathrm{mg}$ resulted in 80. $9 \%$ estrus response (Simonetti, Blanco et al., 2000) .

Higher estrus responses (i.e. 100\%) were observed in Karakul ewes when dosed with $60 \mathrm{mg}$ MAP along with $500 \mathrm{IU}$ of PMSG (Hashemi, Safdarian et al., 2006) . The slight differences between the results obtained in the current study and those reported by other research might be due to the breed of sheep and the season in which the studies were performed.

Lack of significant differences in terms of time to the onset between ewes treated with different eCG doses demonstrate a similar efficiency of the two synchronization methods in inducing estrus during the non-breeding season in the Assaf ewes. The time of estrus onset $(51.3-60.7 \mathrm{hr})$ of the current trial were in agreement with the previous findings of Greyling and Van der Nest, (Greyling and 


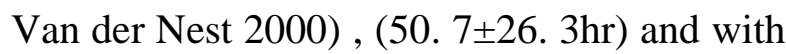
Dogan, (Dogan and Nur 2006) 30 and $60 \mathrm{hr}$. To the contrary, Amer and Hazzaa (Ahmed Amer and Maher Hazzaa 2009) noted that the time from sponge withdrawal to the onset of estrus was delayed in ewes treated with FGA for $12 \mathrm{~d}$. Simonetti et al., (Simonetti, Blanco et al., 2000) recorded estrus to occur 55.94, 56.74 and $57.7 \mathrm{hr}$ after using sponges impregnated with 40, 50, $60 \mathrm{mg}$ progesterone respectively. Comparing the results of this study to those obtained by Akoz et al., (Akoz, Bulbul et al., 2006) who used different concentrations of progesterone in sponges, it is cleared that there was no significant differences between using different progesterone levels in the sponge.

Using higher eCG doses may accelerate the estrus induction after sponge withdrawal. Twelve of the ewes treated with $600 \mathrm{I}$. U eCG showed estrus signs during the first48h. compared to 6 of ewes treated with 300 I. U eCG. The reason of short estrus duration period in this study and the variation in two groups (300IU PMSG and 600IU PMSG) may be due to lower estrogen in blood during the non-breeding season and to breed differences, age and geographical location (EVANS G.; Gordon 1996; Hashemi, Safdarian et al., 2006) . The mean litter size in the eCG groups was estimated to be 1.3 for the ewes injected with 300 I. U. eCG compared to 1.37 for those injected with 600 I. U. eCG. Our results agreed with Pollot and Gootwine (Pollott and Gootwine 2004) who reported that the mean litter size in Assaf breed is 1. 57. Results of this research showed that increasing the eCG dose from 300 to 600 IU had no advantage in increasing twinning rate and litter size although increasing eCG dose has positive effects on improving these parameters.

Gonadotropin hormones function to increase litter size and twining rate, It was reported that the using of 400 I. U PMSG increased the litter size when compared to ewes injected with 200 or 300 I. U. PMSG (de la Cruz, Castañeda et al., 1990; Toteda, Facciolongo et al., 1990). However, in the present study there was noticeably increase in the litter size in $600 \mathrm{IU}$ eCG treated ewes According to the general changes in progesterone hormone levels in Control, 300 I. U and 600 I. U treatment groups, progesterone levels were found statistically significant, at the same time hormone level changes at different measurement times are also significant $(P<0$. 05).

It can be concluded that increasing the dose of eCG was of no advantage since the half dose of eCG has the same effects on number of ovulations and liter size in Assaf breed. The results showed that level of eCG had no significant effects on the tested parameters. This finding indicated that low level of eCG can be successfully applied for estrus synchronization in Assaf breed out of the breeding season. Results showed that using sponge followed by a $300 \mathrm{IU}$ dose of eCG could induce estrus successfully with low cost comparing to application of high doses of eCG.

However, more research on the tested parameters is required especially when dealing with larger herds of ewes.

\section{References}

Ahmed Amer, H. and A. Maher Hazzaa (2009). "The effect of different progesterone protocols on the reproductive efficiency of ewes during the non-breeding season." Veterinarski arhiv 79 (1): 19-30.

Ahmed, M. M., S. Makawi, et al., (1998). "Synchronization of oestrus in Nubian goats." Small ruminant research 30 (2): 113-120. 
Akoz, M., B. Bulbul, et al., (2006). "Induction of multiple births in Akkaraman cross-bred sheep synchronized with short duration and different doses of progesterone treatment combined with PMSG outside the breeding season." BulletinVeterinary Institute in Pulawy 50 (1): 97.

Ataman, M., M. Akoz, et al., (2006). "Induction of synchronized oestrus in Akkaraman cross-bred ewes during breeding and anestrus seasons: the use of short-term and long-term progesterone treatments." Revue de médecine vétérinaire 157 (5): 257.

Ataman, M. B. and M. Aköz (2006). "GnRHPGF2 $\alpha$ and PGF2 $\alpha-P G F 2 \alpha$ synchronization in Akkaraman crossbred sheep in the breeding season." Bull Vet Inst Pulawy 50: 101-104.

Boscos, C., F. Samartzi, et al., (2002). "Use of progestagen-gonadotrophin treatments in estrus synchronization of sheep." Theriogenology 58 (7): 12611272.

Carlson, C. (2000). "The effect of melatonin dosage and progesterone on reproduction in anestrous ewes." California State University Chico, College of Agriculture, available online at:

http://www.csuchico.edu/agr/tempDocs/ ccarlson.html.

Chanvallon, A., D. Blache, et al., (2010). "Sexual experience and temperament affect the response of Merino ewes to the ram effect during the anoestrous season." Animal reproduction science 119 (3-4): 205-211.

De la Cruz, D., M. Castañeda, et al., (1990). Effects of oestrus synchronization by means of FGA-impregnated sponges on the fertility and prolificacy of partly housed pelibuey ewes. Memoria-III Congreso Nacional de Producción
Ovina, Universidad Autónoma de Tlaxcala.

Dogan, I. and Z. Nur (2006). "Different estrous induction methods during the non-breeding season in Kivircik ewes." Veterinarni Medicina-Praha- 51 (4): 133.

EVANS G., M., W.M.C.: Salamon's Artificial Insemination of Sheep and Goats. Butterworths, Sydney, 1986, 194 pp.

Fonseca, J., J. Bruschi, et al., (2005). "Induction of estrus in non-lactating dairy goats with different estrous synchrony protocols." Animal reproduction science 85 (1-2): 117-124.

Goot, H. (1986). Development of Assaf, a synthetic breed of dairy sheep in Israel. Proceedings (Hungary).

Gordon, I. (1996). Controlled reproduction in sheep and goats. CAB International, University Press, Cambridge, UK.

Greyling, J. and M. Van der Nest (2000). "Synchronization of oestrus in goats: dose effect of progestagen." Small ruminant research 36 (2): 201-207.

Hashemi, M., M. Safdarian, et al., (2006). "Estrous response to synchronization of estrus using different progesterone treatments outside the natural breeding season in ewes." Small ruminant research 65 (3): 279-283.

Husein, M. Q. and R. T. Kridli (2002). "Reproductive responses of Awassi ewes treated with either naturally occurring progesterone or synthetic progestagen." Asian Australasian Journal of Animal Sciences 15 (9): 1257-1262.

Karaca, F., M. Ataman, et al., (2009). "Synchronization of estrus with shortand long-term progestagen treatments and the use of GnRH prior to short-term progestagen treatment in ewes." Small ruminant research 81 (2): 185-188. 
Knights, M., Q. Baptiste, et al., (2003). "Effects of dosage of FSH, vehicle and time of treatment on ovulation rate and prolificacy in ewes during the anestrous season." Small ruminant research 50 (1): $1-9$.

O'callaghan, D., F. Karsch, et al., (1991). "What photoperiodic signal is provided by a continuous-release melatonin implant?" Biology of reproduction 45 (6): 927-933.

PCBS (2008) Palestine in Figures 2007 (PNA, P. C. B. o. S., Ramallah, Palestine).

Pollott, G. and E. Gootwine (2004). "Reproductive performance and milk production of Assaf sheep in an intensive management system." Journal of dairy science 87 (11): 3690-3703.

Rad, A. F. and N. Farzaneh (2007). "Effect of CIDR and Different Doses of PMSG on Pregnancy and Lambing Rate out of Breeding Season in Balouchi Ewes." Journal of Animal and Veterinary Advances 6 (10): 1167-1171.

Rosa, H. and M. Bryant (2002). "The 'ram effect'as a way of modifying the reproductive activity in the ewe." Small ruminant research 45 (1): 1-16.

Simonetti, L., M. Blanco, et al., (2000). "Estrus synchronization in ewes treated with sponges impregnated with different doses of medroxyprogesterone acetate." Small ruminant research 38 (3): 243 247.

Sözbilir, N. B., Ş. Maraşli, et al., (2006). "Effects of Double Injections of PGF $\{2\} \backslash a$ lpha at Different Intervals on Some Reproductive Traits in Tuj Ewes." Turkish Journal of Veterinary and Animal Sciences 30 (2): 207-211.

SPSS INC: SPSS 16 for windows. Statistical package for the social. Sciences. Chicago, U., 2008, www.spss.com.

Stellflug, J., J. Fitzgerald, et al., (1988). "Influence of concentration, duration and route of administration of melatonin on reproductive performance of springmated Polypay and Polypay-cross ewes." Journal of animal science 66 (8): 1855-1863.

Timurkan, H. and H. Yildiz (2005). "Synchronization of oestrus in Hamdani ewes: The use of different PMSG doses." Bulletin-Veterinary Institute in Pulawy 49 (3): 311.

Toteda, F., A. Facciolongo, et al., (1990). "Effect of PMSG dose and presence of the male on control of the oestrus in cyclic ewes." Zootecnica e Nutrizione Animale 16 (4): 263-270.

\section{How to cite this article:}

Hatem Atalla. 2018. The Effects of Different Doses of Equine Chorionic Gonadotropin on Induction of Estrus and Reproductive Patterns in Assaf Ewes out of Breeding Season. Int.J.Curr.Microbiol.App.Sci. 7(06): 2078-2085. doi: https://doi.org/10.20546/ijcmas.2018.706.245 